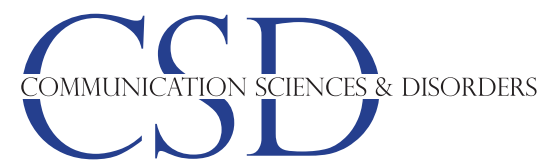

Erratum

| ISSN 2288-0917 (Online) | Commun Sci Disord 2017;22(4):851

https://doi.org/10.12963/csd.17403e1

\title{
Prevalence of Speech Sound Disorders in 6-Year-Old Children in Korea
}

\author{
Soo-Jin Kim ${ }^{\mathrm{a}}$, Yoo-Kyeong Ko ${ }^{\mathrm{b}}$, Eun-Young Seo ${ }^{\mathrm{b}}$, Gyung-Ah Oh ${ }^{\mathrm{b}}$ \\ ${ }^{a}$ Department of Communication Disorders, Korea Nazarene University, Cheonan, Korea \\ ${ }^{b}$ Department of Communication Disorders, The Graduate School of Korea Nazarene University, Cheonan, Korea
}

\section{우리나라 6세 아동의 말소리장애 출현율}

김수진 ${ }^{1}$ 고유경 $\cdot$ 서은영 $\cdot$ 오경아

${ }^{1}$ 나사렛대학교 언어치료학과, ${ }^{2}$ 나사렛대학교 일반대학원 언어치료학과

Commun Sci Disord 2017;22(2):309-317

https://doi.org/10.12963/csd.17403

The funding acknowledgment in this article was omitted as published. Additional acknowledgment is as follows:

This work was supported by the research fund of Korea Nazarene University in 2017.

다음과 같이 Acknowledgement가 추가되어 수정합니다.

본 연구는 2017년도 나사렛대학교 연구비 지원에 의하여 수행되었음. 